\title{
Kristen bioetikk på defensiven
}

\author{
Morten Magelssen
}

Senter for medisinsk etikk, Institutt for helse og samfunn, Universitetet i Oslo magelssen@gmail.com

I takt med sekulariseringen av Norge har den kristne bioetikken mistet innflytelse. For klassisk kristen etikk har det vort mange nederlag de siste tiårene. Men det har skjedd noe mer enn at klassiske kristne posisjoner har mistet tilslutning. De kristnes argumenter har også mistet appell og gjennomslagskraft $i$ det offentlige rom, $i$ en grad som ikke alene kan forklares med at antallet kristne synker. Artikkelen identifiserer fem hovedgrunner til at kristne argumenter i bioetikken ikke får gjennomslag i offentligheten: politisk liberalisme, avvisningen av religiøs argumentasjon, avvisningen av unntaksløse moralske forbud, moralsk subjektivisme og relativisme, og avvisning av handlingers symbolverdi. Grunnene drøftes med eksempler fra offentlig debatt.

Nøkkelord: bioetikk, kristen etikk, naturrett, politisk liberalisme

\section{English summary: Christian bioethics on the defensive}

In Norway, Christian bioethics has lost influence in step with secularization. For classical Christian ethics there have been numerous defeats in recent decades. However, something more than a simple decline in support for classical Christian positions has taken place. Christian arguments have also lost appeal and impact in the public square, to a degree that cannot be explained merely by the falling rate of adherence to Christianity. The article identifies five major reasons why Christian arguments in the sphere of bioethics fail to have an impact in the public square: political liberalism, the rejection of religious argumentation, the rejection of moral absolutes, moral subjectivism and relativism, and the rejection of the symbolic value of actions. The reasons are discussed with examples from the public debate.

Keywords: bioethics, Christian ethics, natural law, political liberalism

\section{Innledning}

Bioetikk er etiske spørsmål som oppstår i kjølvannet av vitenskapelige fremskritt innen bioteknologi og medisin. Klassisk eller tradisjonell kristen bioetikk kjennetegnes blant annet ved at det legges vekt på respekt for menneskeverdet, ikke minst ved livets begynnelse og slutt. Fra ståstedet til klassisk kristen bioetikk er denne respekten for menneskeverdet i ferd med å uthules. ${ }^{1}$ 
Fra et gitt ståsted i tid og rom vil det ideologiske landskapet fremstå mangefasettert og komplekst. Eventuelle trender avtegner seg tydeligst i et fugleperspektiv. Min påstand er at hvis vi ser på de siste 60 årene, er utviklingen for klassisk kristen bioetikk tydelig negativ, og trolig akselererende. Blant nederlagene er loven om selvbestemt abort (1978), liberaliseringen av bioteknologiloven (2007) som åpnet for forskning på befruktede egg, genetisk undersøkelse av embryoer (preimplantasjonsdiagnostikk) og fremstilling av «donorsøsken», assistert reproduksjon for lesbiske par (2009) samt bortfallet av fastlegers reservasjonsmulighet ved etisk omstridt behandling (2011). I tillegg er fosterdiagnostisk «tidlig ultralyd» og blodprøve av mor samt utvidelse av tilbudet om assistert reproduksjon til nye grupper dagsaktuelle politiske spørsmål.

Det skulle kanskje ikke være annet å vente i et Norge der stadig færre regner seg som kristne. I 2012 oppga 50 prosent at kristendommen var det livssyn som lå nærmest deres eget. Fire år tidligere var andelen 59 prosent. Men jeg vil hevde at tendensen ikke bare er at færre bekjenner seg til de tradisjonelle kristne standpunktene. Mer påfallende er det at argumentene som springer ut av klassisk kristen etikk, synes å miste mye av sin kraft i møte med ikke-kristnes motargumenter. I offentlig debatt tas kristne argumenter mindre alvorlig; de er lette å avfeie, de er oftest impotente i politikken, og de kan fremstå irrelevante for dem som ikke deler det tilgrunnliggende kristne verdensbildet. Hvorfor?

Jeg vil diskutere grunner til at kristnes argumenter så ofte oppfattes som irrelevante og har liten gjennomslagskraft, og gi eksempler på slike grunner i praksis. Derigjennom peker jeg på trekk ved vår samtid som kristne vil være kritiske eller i det minste ambivalente til. Men heller ikke ikke-kristne bør uten videre være komfortable med disse trekkene. Fokus er på trekk ved det offentlige ordskiftet, men det vil også trekkes tråder til underliggende premisser fra akademisk filosofi.

Artikkelen peker på rasjonelle grunner til at kristnes argumenter mister sin kraft, i motsetning til ikke-rasjonelle grunner. Om rasjonelle grunner kan man spørre: Er dette virkelig (normativt) en god grunn for X? (der X er et handlingsalternativ eller en oppfatning). En eksistens av antipatier mot kristne eller av lav medieeksponering for kristne standpunkter ville være eksempler på ikke-rasjonelle grunner, og eventuelle slike trender er altså ikke tema her. Grunnene drøftes under fem hovedoverskrifter: bioetikk i det liberale samfunn, avvisning av religiøs argumentasjon, avvisningen av unntaksløse moralske forbud, moralsk subjektivisme og relativisme, og avvisning av handlingers symbolverdi.

En slik analyse av ideologiske og filosofiske trender står i fare for å bli unyansert hvis den ikke tar hensyn til eksempler som taler i motsatt retning. For klassisk kristen bioetikk finnes det nemlig også mange lyspunkter, slik som helsepersonells og politikeres motstand mot eutanasi, forbudet mot kloning og grundige offentlige debatter om fosterdiagnostikk og surrogati der motstanderne kommer sterkere til orde enn i mange andre vestlige land. I tillegg kommer det faktum at helsetjenestens verdigrunnlag fortsatt er preget av kristne idealer som barmhjertighet, nestekjærlighet og rettferdighet.

Dermed er det hovedsakelig fra fugleperspektivet at dagens situasjon plausibelt kan beskrives som kritisk for tradisjonell kristen bioetikk: Det er retningen offentlig debatt beveger seg i, og hastigheten det skjer med, som fra kristen bioetikks perspektiv gir størst grunn til bekymring. Trendene som beskrives under, er sterke, men ikke entydige eller enerådende. 


\section{Bioetikk i det liberale samfunn}

I akademisk politisk filosofi står moderne politisk liberalisme sterkt (Rawls 1996). Dens prinsipper har intuitiv appell og har trengt inn i de fleste vestlige politiske partier, også i Norge. Vår tid er kjennetegnet ved etisk, religiøst og kulturelt mangfold. Liberalismen håndterer dette mangfoldet ved å si at staten så langt det er mulig, ikke skal ta parti. Staten skal forbli nøytral i spørsmålet om hva det gode liv er. Staten må ikke felle dommer over borgernes livsstiler og legitime preferanser. En preferanse er legitim hvis den ikke skader andre, i tråd med John Stuart Mills «harm principle»: «The only purpose for which power can be rightfully exercised over any member of a civilized community against his will, is to prevent harm to others [...] Over himself, over his body and mind, the individual is sovereign» (Mill 1865: 6).

I lys av nøytraliteten må preferanser som hittil har møtt samfunnets skepsis, vurderes på nytt. Dette har gitt utslag som også klassisk kristen etikk vil regne som fremskritt, slik som avkriminaliseringen av homofili. Men andre utslag er mer problematiske. Eksempelvis, etter lobbyvirksomhet ble sadomasochisme fjernet fra den medisinske diagnoselisten ICD-10 i 2010. Ved dette ble sadomasochisme «normalisert», som et livsstilsvalg en liberal stat må behandle nøytralt. Nøytraliteten innebærer rett til offentlig støtte på lik linje med andre livsstilsvalg, og foreningen SMil Norge fikk følgelig tilskudd til en brosjyre om sadomasochisme som blant annet skulle distribueres på helsestasjoner for ungdom. Departementets talsperson uttalte at «brosjyren holder høy faglig kvalitet, og lykkes med å avmytologisere SM. Etter at diagnosen ble avviklet i 2010, er det viktig å gi god informasjon som kan styrke grupper som lenge har blitt diskriminert» (Gustavsen \& Murtnes 2012).

Arbeiderpartiet, Sosialistisk Venstreparti og Venstre har foreslått at nye grupper skal få adgang til assistert reproduksjon, bekostet av staten. Fra statens perspektiv skal homofile og lesbiske samboerskap, partnerskap og ekteskap likebehandles med heterofile samlivsformer. Og når disse gruppene, samt enslige, ønsker seg barn, følger det at staten må legge til rette for dette på samme måte som de gjør for heterofile par. Ettersom sæddonasjon lenge har vært tillatt, tilsier prinsippet om likebehandling at også egg- og embryodonasjon må tillates.

Fordi vi er frie og uavhengige individer og er i stand til å sette oss våre egne mål, trenger vi et moralsk og juridisk rammeverk som behandler alle slike mål likt, hevder liberalismen (Sandel 1998: 187). Den ortodokst kristne bioetikeren H. Tristram Engelhardt jr. $(1996,2000)$ peker på at én respons har vært å utvikle en liberal «bioetikk for moralske fremmede ('moral strangers')». Bioetikken har sluttet å uttale seg om hvilke valg som fremmer eller hemmer det gode liv, for i vår tid er dette spørsmål uten endelige svar. Det finnes tallrike og høyst ulike oppfatninger om hva det gode liv er. Bioetikken er blitt innholdsfattig («content-thin») og prosedural, et redskap til at «moralsk fremmede» mennesker med motstridende moralske verdensbilder likevel kan leve sammen - ved at de tolererer hverandres forskjeller (Engelhardt 1996, 2000).

Det overordnede moralske prinsippet i en slik bioetikk blir nettopp selvbestemmelsesretten. En preferanse som ikke er påvist å skade andre (jf. Mills «harm principle»), har krav på aksept og tilrettelegging. Arbeiderpartiet hevdet at det var et tungt og selvstendig 
argument for offentlig bekostet «tidlig ultralyd» for alle at undersøkelser viste at noen gravide, særlig i byene, kjøper undersøkelsen på det private marked (Helsedirektoratet 2011: 144; Marthinsen 2011). Et offentlig finansiert tilbud ble derfor fremhevet som nødvendig for å fjerne sosiale og geografiske hindre for at gravide skal få oppfylt sine preferanser og derved utøvet sin autonomi.

Venstres Guri Melby viser hvordan den liberale bioetikkens grunnprinsipper kommer til anvendelse på assistert reproduksjon:

Så lenge det ikke går på bekostning av andres liv og velferd, mener jeg den enkelte borger i størst mulig grad må få velge sin egen retning i etiske spørsmål. [...] Spørsmålet om hvordan man bringer sine egne barn til verden, er så personlig og nært for de fleste av oss at jeg tror de etiske valgene må komme fra oss selv, ikke fra et politisk flertall på Stortinget. Da må lovverket gi oss rom. Og politikerne vise oss tillit. (Melby 2012)

Siden den liberale bioetikken mangler innhold, må vi selv fylle den - og hva vi fyller den med, har ikke andre noe med.

Hva skjer hvis det argumenteres mot å utvide assistert reproduksjon til nye grupper, med argumenter fundert i kristne oppfatninger om det heterofile ekteskapets særstilling? Slik argumentasjon kan av liberal bioetikk bli avvist som irrelevant og sekterisk, og i tillegg fordomsfull og uetisk, fordi den i strid med liberalismens grunnprinsipp kan tolkes som å implisere at én livsstil er mer høyverdig enn visse andre.

\section{Avvisning av religios argumentasjon}

Det hevdes ofte at religion hører hjemme i privatsfæren, og at religiøs argumentasjon ikke har noen plass i det offentlige rom når politiske veivalg diskuteres. SVs Bård Vegar Solhjell skriver for eksempel:

Det er etter mitt syn fundamentalt feil å la religiøse idear vere styrande over menneskelege idear om kva som er godt for oss menneske [...]. I eit fleirreligiøst samfunn vil det eine livssynet vere det andre si framandgjering dersom det vert gjort om til prinsipp og praksisar som skal gjelde alle, gjennom staten og institusjonane under staten. (Solhjell 2013: 44-45)

En slik oppfatning får støtte i filosofiske teorier om «public reason». ${ }^{2}$ I et pluralistisk samfunn holder borgerne ulike moralske verdensbilder eller "comprehensive doctrines». Men borgerne må innse at de ikke kan oppnå gjensidig forståelse eller enighet med argumentasjon basert i sine respektive moralske verdensbilder, uforenlige som disse er (Rawls 1997: 766). Den som utøver politisk makt, må kunne rettferdiggjøre sine avgjørelser overfor alle borgere. Til dette trengs argumenter som alle borgere rasjonelt bør kunne forstå og akseptere, uavhengig av de partikulære moraloppfatningene som skiller borgerne.

Hvordan kan man da argumentere for tradisjonelle kristne bioetiske standpunkter? Det er kun akseptabelt hvis argumentene fremføres i en allmennetisk form, avkledd alle eksplisitte referanser til kristne tradisjoner og Bibelen. Kun da oppfyller argumentene 
kravet fra «public reason» om at også ikke-kristne i prinsippet vil kunne forstå, vurdere og akseptere argumentene.

Hva er det som gjør argumentasjon religiøs? Strengt tatt kan et argument som sådan ikke være religiøst, for logiske slutninger er verken religiøse eller sekulære. Det er snarere premisser og konklusjoner som kan være religiøse, og da særlig på to måter (Audi 1993): Innholdsreligiøsitet oppstår når det essensielle innholdet i et utsagn er religiøst, slik som referanser til Guds vilje, til hellige tekster eller til religiøse autoriteter. Epistemisk religiøsitet innebærer at utsagnet ikke er religiøst på grunn av sitt innhold, men på grunn av hvordan det må begrunnes. Hvis konklusjonen eller bakenforliggende premisser ikke kan begrunnes uten å ty til religiøse kilder, har vi å gjøre med epistemisk religiøs argumentasjon.

Naturretten er den kristne etiske tradisjonen som fremfor noen er kompatibel med «public reason»-tenkningen. Naturretten legger vekt på Gud som den fornuftige «lovgiver» og at Guds vilje i etikkens domene i stor grad er erkjennbar for menneskelig fornuft (Murphy 2008; Magelssen 2010). Dermed kan etiske sannheter (også) gis en allmennetisk fremstilling og innpakning.

Et problem for kristen etikk er at ikke alle etiske utsagn kan «oversettes» til allmennetikkens form og språk uten at noe går tapt på veien. For eksempel, at Gud har skapt mennesket i sitt bilde, at menneskets høye verdi springer ut av dette, og at Guds omsorg for mennesket begynner allerede på fosterstadiet, er et argument som - hvis man først aksepterer det kristne verdensbildet - er høyst plausibelt. Den sterkeste naturrettslige ekvivalenten fremhever at menneskets verdi springer ut av dets rasjonelle natur, og at mennesket besitter rasjonell natur og dermed verdi allerede fra fosterstadiet (Beckwith 2007; George \& Tollefsen 2008; Kaczor 2011). Men, det første, innholdsreligiøse argumentet er mer robust fordi premissene her - forutsatt et kristent verdensbilde - er mindre kontroversielle enn i det andre, allmennetiske argumentet, der premissene kan angripes fra en lang rekke innfallsvinkler (Magelssen 2011). Kristen bioetikk mister noe av sin overbevisningskraft når den første typen argumenter utelukkes fra debatten.

Avvisningen av religiøs argumentasjon innebærer at vårt lands kristne tradisjoner ikke skal ha betydning for dagens beslutninger. Dermed blir det for eksempel irrelevant $\mathrm{i}$ debatten om eutanasi (aktiv dødshjelp) at et fortsatt forbud støttes av forbudet mot drap og selvdrap i den kristne tradisjonen. Alle politiske beslutninger må i prinsippet kunne begrunnes av universelle og «tidløse» argumenter løsrevet fra partikulære tradisjoner. I akademia tas et sekulært utgangspunkt gjerne for gitt, mens forskning og formidling informert av et kristent verdensbilde, gjerne er forvist til de teologiske fakultetene (Marsden 1997).

Det at gangbare grunner i den offentlige debatt må kunne forstås og aksepteres av alle, gir empirisk vitenskap en prominent plass. For empiri er kunnskap om sammenhenger, årsaker og korrelasjoner som gjør krav på gyldighet for alle borgere uavhengig av disses partikulære verdensbilder og ideologier. I vår kultur som setter vitenskapen så høyt, er empirien et lingua franca. Dens autoritet fortrenger andre tradisjonelt velansette kilder til (moralsk) kunnskap, slik som refleksjoner basert på menneskets normative natur. I tradisjonell kristendom er refleksjoner over menneskets natur en viktig kilde til moralsk inn- 
sikt. I klassisk naturrettstenkning er denne koblingen helt eksplisitt: Refleksjon over menneskenaturen viser oss hvilke formål som lar oss realisere vår natur på best mulig måte, og en handling er i tråd med vår natur når den bidrar til å realisere denne naturen. Tilsvarende er en handling «unaturlig» hvis den hindrer oss i å realisere vår natur.

En slik oppfatning av menneskenaturen som normativ står i fare for å bli dobbelt forbudt i det politiske klimaet som skisseres her. For det første synes den å være epistemisk religiøs som definert ovenfor, en anklage som spesielt gjør seg gjeldende når det er snakk om seksualetikk. For det andre leder den til et partikulært og ikke-nøytralt syn på hva det gode liv for mennesket er. Den liberale nøytraliteten krever derfor at den nevnte forståelsen ikke får gjennomslagskraft i offentlig debatt. Det er verdt å merke seg at en liberal bioetikk også nødvendigvis må holde seg med en viss, normativ oppfatning av menneskenaturen. Men denne oppfatningen vil være «tynn» (innholdsfattig) og først og fremst fremheve menneskets autonomi og frihet (Habermas 2003).

I debatten om hvorvidt assistert reproduksjon også skal være et tilbud til andre enn heterofile par, og om kjønnscelledonasjon skal være tillatt, er tradisjonell kristen etikks mest potente argumenter nettopp fundert i tanken om normativ menneskenatur. For eksempel er det naturlig (i naturrettslig forstand) for barn å vokse opp med begge biologiske foreldre. Men når denne argumentasjonsveien er stengt, blir spørsmålet om naturlig og unaturlig i stedet transformert til et empirisk spørsmål: Kan forskningen påvise relevante forskjeller mellom barn som vokser opp henholdsvis hos begge biologiske foreldre og $\mathrm{i}$ andre familiekonstellasjoner? For å forsvare tradisjonelle kristne etiske standpunkter er man dermed forpliktet til å følge den empirisk-vitenskapelige logikken og de spillereglene som gjelder der. Dette er problematisk fordi noen av de spørsmålene som er aller viktigst for oss mennesker - slik som etiske spørsmål og spørsmål om mellommenneskelig interaksjon - vanskelig lar seg besvare vitenskapelig. Når empirisk vitenskap blir så viktig, blir også spørsmål om forskningens kvalitet og omfang, eventuelle slagsider og metodologiske utfordringer helt sentrale spørsmål i offentlige debatter.

Den liberale bioetikkens prinsipper tilsier at tilbudet om assistert reproduksjon bør utvides ytterligere, noe som nå er et politisk stridstema. Samfunnet har lenge akseptert sæddonasjon for heterofile par der mannen er infertil. Dermed tilsier de liberale prinsippene om likestilling og likebehandling av livsstiler og preferanser at også eggdonasjon, embryodonasjon og surrogati skal tillates, for enslige og par i ulike konstellasjoner. Det eneste som kunne torpedere denne liberaliseringslogikken ville være gjennom forskning å påvise negative konsekvenser av å utvide tilbudet.

Kristne har også forsøkt å utnytte empiriens makt til sin fordel, men ikke nødvendigvis med hell. I USA hadde kristne abortmotstandere registrert at tradisjonelle moralske argumenter ble stadig mindre potente. Derimot var det mange rapporter om at abort kunne utløse sorgreaksjoner. Man forsøkte derfor en «new rhetorical strategy» (Beckwith 2001; Reardon 2002) der sorgreaksjonene ble «oppgradert» til psykiske lidelser i tråd med medisinske diagnosemanualer og forsøkt ikledd den status som tilligger medisinske diagnoser (Dadlez \& Andrews 2009; Lee 2003). De moralske argumentene som ikke lenger var effektive, skulle erstattes av nye argumenter som kunne snakke medisinens prestisjetunge språk; i stedet for impotente argumenter om at abort er galt, hevdet man at kvinner 
tar skade av å gjennomgå abort. Problemet var bare at dette slett ikke lot seg dokumentere. I den nyeste og metodologisk mest grundige gjennomgangen av forskningsfeltet er konklusjonen at abort $i k k e$ leder til psykiske lidelser hos uønsket gravide (Academy of Royal Medical Colleges 2011). En mulig forklaring på dette er at kvinner kan få plager etter abort, men at disse plagene sjelden tar form av påvisbare psykiske lidelser som oppstår i studienes begrensede observasjonstid, men snarere som sorgreaksjoner som kan oppstå etter lang tid.

Et annet eksempel er at kristne forskere har kastet seg over det nye forskningsfeltet "sammenhenger mellom tro og helse», noen med eksplisitt forventning om å avdekke kausalsammenhenger mellom aktiv religiøsitet og god helse. Indikasjoner på noen slike kausale sammenhenger er påvist (Koenig, King \& Carson 2012), men feltet er hjemsøkt av store metodeutfordringer (Sloan 2006). Poenget her er at den store interessen feltet har vakt, både hos forskere og i den kristne dagspressen, tydelig demonstrerer empiriens kraft og posisjon i vårt samfunn. Satt på spissen kan vi si at spørsmålet om kristendommens sannhet er blitt forsøkt operasjonalisert til et spørsmål som empirisk vitenskap kan besvare: hvorvidt kristen praksis gir gode, målbare konsekvenser.

\section{Avvisning av unntakslose moralske forbud}

Et moralsk absolutt er en moralsk regel som er gyldig alltid, uavhengig av omstendighetene. Negative moralske absolutter er unntaksløse forbud. I klassisk kristen etikk finnes et lite knippe slike unntaksløse forbud. I bioetikken spiller de en viktig rolle ved spesielt å begrunne forbud mot abort, destruksjon av embryoer og eutanasi. Men slike moralske absolutter er vanskelig å begrunne i et ikke-religiøst verdensbilde. Den profilerte eutanasimotstanderen Morten Horn, som er humanetiker, gjør rede for hva som skiller ham fra religiøse meningsfeller: «Den absolutismen som [prinsipiell avvisning av eutanasi] innebærer er i hvert fall vanskelig å godta for meg som rasjonalist og humanetiker» (Horn 2010). Horns sterke forsvar for et fortsatt forbud mot eutanasi begrunnes snarere i at legalisering vil ha store uheldige konsekvenser - for pasienter, helsepersonell og samfunn.

Dette peker mot en annen trend: den sekulære dragning mot konsekvensetikk. Flere sekulære etiske teorier, slik som visse former for pliktetikk i tradisjonen etter Kant, forsvarer moralske absolutter. Men det er likevel noen trekk ved moderne naturalistiske (ateistiske eller agnostiske) verdensbilder som gjør konsekvensetikk mer attraktivt, på bekostning av pliktetikken og dens moralske absolutter. Det gjelder særlig fraværet av en transcendent moralsk lovgiver. Uten Gud blir moralske absolutter ofte nedgradert til veiledende tommelfingerregler. Slike regler vil vi avvike fra når det gir utsikt til bedre konsekvenser.

Avvisningen av absoluttene viser seg i det moralske språket. Hvis embryoer er mennesker i livets tidligste fase, med den samme moralske verdi som fødte mennesker, skal man ikke ta livet av embryoer for å forske på dem (George \& Tollefsen 2008; Østnor 2008). De moralske absoluttene er «trumfkort»; de tillater ingen unntak eller overtredelser. I kontrast til dette snakker mange om «etiske kostnader» og «moralske utfordringer», 
på en måte som om etiske innvendinger kun er relative hindre som prinsipielt alltid kan oppveies av utsikten til gode konsekvenser. Klassisk kristen etikk insisterer imidlertid på at visse handlinger i sin natur alltid er moralsk uakseptable.

Konsekvenser vil altså tendere til å trumfe (absolutte) prinsipper. Dette gjør kristen pliktetikk sårbar for ekstreme enkelttilfeller. Et biopolitisk eksempel er Mehmet-saken fra 2004 (Antonsen \& Levold 2011). Mehmets foreldre ønsket å lage et «donorsøsken» egnet til beinmargstransplantasjon. Dette var forbudt, og de negative konsekvensene av forbudet fanget medienes oppmerksomhet. Det gjorde derimot ikke kristen etikks prinsipp om ikke å skape embryoer som siden blir destruert. (Det felles kristne og humanistiske prinsippet om ikke å skape mennesker som midler mer enn mål i seg selv, derimot, fikk spille en rolle i debatten.)

Den kristne etikkens moralregler, og i særdeleshet absoluttene, står videre i fare for å miste sin appell når de løsrives fra den større tradisjon og sammenheng som opprinnelig ga dem mening. Om dette skriver Alasdair MacIntyre:

Detach them [moralreglene] from their place in defining and constituting a whole way of life and they become nothing but a set of arbitrary prohibitions, as they too often become in later periods. To progress in both moral enquiry and the moral life is then to progress in understanding all the various aspects of that life, rules, precepts, virtues, passions, actions as parts of a single whole. (MacIntyre 1990: 139)

Tilsvarende påpeker Engelhardt at

[...] we live in the ruins of Christendom. We are left with fragments of moral intuitions from a once intact way of life. These fragments remain as hesitations that cannot ultimately be defended but nevertheless persist as powerful but unsecured taboos. (Engelhardt 2000: xii)

Engelhardt provoserer ved å trekke frem forbudet mot spedbarnsdrap som eksempel på et tabu som ikke lar seg begrunne i sekulær bioetikk. Men også noen ateistiske filosofer er enige med ham $i$ at sett ut fra Vestens liberale abortpraksis, må dette forbudet ses på nettopp som et ubegrunnet tabu (Giubilini \& Minerva 2013; Tooley 1972).

Skal vi tro MacIntyre og Engelhardt, kan vi forvente at vårt land, hvis sekulariseringen fortsetter, i økende grad vil ta avstand fra de gjenværende fragmentene av tradisjonell kristen bioetikk. Noe av kristen bioetikk kan begrunnes også innen et liberalt paradigme og kan derfor overleve. Andre ting vil bli ansett som ubegrunnbare fordommer, og blir forkastet.

\section{Moralsk subjektivisme og relativisme}

I kristen etikk er Gud den moralske lovgiver og den ultimate garantist for etikkens betydning. I et verdensbilde uten Gud må etikken begrunnes på en annen måte. Hvis denne begrunnelsen uteblir, kan etikken fremstå som noe subjektivt, slik den fort gjør i et rent scientistisk eller positivistisk paradigme. ${ }^{3}$ 
En far som valgte fosterdiagnostikk og selektiv abort, forsvarte sin beslutning i en kronikk: «Du kan aldri fullt og helt forstå noe du ikke har opplevd og erfart selv. [...] Enhver utenforstående vurdering vil måtte bli subjektiv» (Skancke 2007). Skribenten er kritisk til «prinsipielle funderinger fra akademiske og politiske hold» og «mennesker med en teoretisk innfallsvinkel til temaet». I hans etiske system blir den subjektive opplevelsen avgjørende, og den handlendes følelser trumfkortet. Siden ens egne følelser ikke kan overprøves av noen andre, kan heller ikke ens etiske beslutning overprøves. Dette står i skarp motstrid til kristen etikk, som hevder at det finnes handlinger som i seg selv er gale, uavhengig av de involvertes følelser. Men for denne faren vil en slik påpekning av objektiv etisk klanderverdighet være problematisk: «Å bruke begrepet sorteringssamfunn [...] [får] den konsekvens at mange enkeltmennesker blir stigmatisert og stemplet for å ta mindre moralske valg enn det man selv gjør.»

Moralsk subjektivisme tar mye av brodden av klassisk kristen bioetikks kritikk av visse praksiser. For eksempel vil kristen bioetikk være kritisk til fosterdiagnostikk og selektiv abort fordi dette impliserer at menneskers verdi varierer ut fra individets sykdomstilstander og andre egenskaper. Dette likeverdsargumentet mot fosterdiagnostikk og selektiv abort sier altså at disse praksisene innebærer å benekte en del av vårt samfunns etiske fundament, nemlig alle menneskers likeverd (Magelssen \& Materstvedt 2013). En subjektivist vil benekte at handlinger kan ha slike objektive implikasjoner. For ham er moralske utsagn først og fremst uttrykk for talerens oppfatning. I dette perspektivet vil en legge størst vekt på at fosterdiagnostikk og selektiv abort kan oppfattes som sårende av fødte personer med de aktuelle tilstandene (Helsedirektoratet 2011: 142). Dette er riktig nok, men som et etisk argument er det mindre potent enn likeverdsargumentet.

En viss relativisme er også innebygd i luthersk kristendom. Det er den enkelte kristne med sin samvittighet, ikke kirkelige læreautoriteter, som tolker Bibelen og de kristne etiske bud. Men siden Bibelen ofte ikke gir entydig etisk veiledning, spesielt ikke for bioetiske dilemma som først har blitt aktuelle i vår tid, er det derfor svært stort rom for ulike oppfatninger blant kristne. Eksempelvis støtter den australske gruppen «Christians Supporting Choice for Voluntary Euthanasia» innføringen av eutanasi, og de hevder at dette ikke er i strid med kristen etikk. Lutheranismens innebygde relativisme bidrar til at eutanasiforbudet og andre klassiske kristne standpunkter i bioetikken utfordres i vår tid.

\section{Avvisning av handlingers symbolverdi}

I tradisjonell kristendom er refleksjon over handlingers symbolverdi en viktig kilde til etisk innsikt. En handlings symbolisme er en etisk veiviser, og negativ symbolisme er en pekepinn på at en handlingstype ikke er forenlig med Guds plan for verden. Argumenter fundert i handlingers symbolikk, er ikke minst aktuelle på feltet assistert reproduksjon. Ved kommersiell surrogati, hevdes det, blir barnet en handelsvare, ettersom det finnes både kjøpere, en selger, kontrakter og bakmenn (Meilaender 2005; O’Donovan 1984). Klassisk kristen bioetikk vil hevde at dette i seg selv er et viktig etisk argument. Det at barnet blir en handelsvare, er uforenlig med respekten for barnets menneskeverd. I 
kristen etikk kan denne negative symbolverdien være så betydningsfull at det i seg selv er et helt avgjørende argument mot surrogati.

I offentligheten er det mange som avviser dette argumentet. En mann som ble far gjennom surrogati, skriver: «Min datter er mitt barn, ikke mitt 'erstatningsbarn'. Jeg har ikke kjøpt henne. Hun er ikke en vare» (Eid-Hviding 2012). Her avviser han at det i det hele tatt er noen relevant symbolikk knyttet til datterens tilblivelse. For ham fremstår tilskrivelsen av symbolverdi til denne tilblivelsen ikke som påpekning av moralsk relevante fakta, men snarere som en retorisk stempling som både er upassende og blir et substitutt for relevante etiske argumenter. I et naturalistisk verdensbilde, der universet er et lukket system uten plass til Gud, og der alt som skjer, i prinsippet er rene naturprosesser, er det i det hele tatt vanskelig å skulle tillegge handlingers symbolverdi noen etisk betydning. Hvis universet i seg selv er formålsløst, er handlingers symbolikk ikke noen veiviser mot moralske fakta nedlagt i verden av en skaper.

Et annet eksempel: I en artikkel drøfter Moen (2012) hvorvidt prostitusjon er skadelig. Han konkluderer med at det i seg selv ikke er skadelig, etter blant annet å ha tilbakevist at salg av sex innebærer objektifisering eller å «selge sin sjel» i moralsk relevant forstand. I kristen etikk, derimot, vil nettopp disse innvendingene stå sentralt. Handlingene involvert i prostitusjon, har sterk, negativ symbolikk knyttet til seg, noe som peker mot at prostitusjon ikke er forenlig med menneskets verdighet.

Samtidig vil ikke en appell til handlingers symbolverdi i alle sammenhenger være et slag i luften. Eksempelvis er forbudet mot kjøp og salg av humant biologisk materiale dels begrunnet i symbolikken knyttet til slikt kjøp og salg. Dette forbudet synes å ha bred støtte, selv om det også utfordres av bioetikere (se f.eks. Erin \& Harris 2003).

\section{Kristen bioetikk: en tapt sak?}

En kristen som ville ønske å rehabilitere kristen bioetikk og dens påvirkningskraft i det offentlige rom, vil ha en tung oppgave. Det innebærer å kjempe mot dyptgående ideologiske og filosofiske trender i vår tid, trender som igjen er knyttet til politisk liberalisme, ateisme og vitenskapelig naturalisme. En strategi som for noen vil fremstå som mest lovende, er derfor frimodig å fremheve kristendommen som et troverdig verdensbilde med sannhetspretensjoner. Kun hvis det kan sannsynliggjøres at kristendommen er epistemisk sann, blir det i neste omgang rom for også å sannsynliggjøre den kristne bioetikken. Denne etikken er i mangt avhengig av et tilgrunnliggende kristent verdensbilde, og derfor må dette på plass først før noen lar seg overbevise om bioetikken.

En annen strategi vil være å angripe de fem trendene som er presentert her. Et første skritt er å avsløre disses funksjon som ofte uuttalte, tilgrunnliggende premisser i bioetiske spørsmål, slik det er gitt mange eksempler på her. Neste skritt er å kritisere trendene på prinsipielt grunnlag. For eksempel, politisk liberalisme og avvisningen av religiøs argumentasjon har blitt kritisert for å fremstille partikulære, kontroversielle oppfatninger om offentlighet og politisk debatt som om de var nøytrale teser som burde være akseptable for alle (Kalb 2008; Sandel 1998). De tankemessige trendene kan også kritiseres ved sine 
implikasjoner. Leder for eksempel politisk liberalisme og avvisningen av naturrettstanken med nødvendighet til aksept for surrogati? I så fall vil dette for mange være en uakseptabel implikasjon. Blir det tilstrekkelig mange slike, bør en revurdere premissene som ligger til grunn. Dernest må det pekes på alternativer. I en klassisk kristen liberalisme, som et alternativ til moderne politisk liberalisme, er friheten ikke til for å realisere enhver preferanse, men for å ha rom til å handle fornuftig, i tråd med de skrankene etikken setter.

I denne artikkelen har jeg argumentert for to påstander. For det første at tradisjonell kristen bioetikk får mindre gjennomslag i politiske beslutninger enn før. Som belegg for dette har jeg anført en rekke biopolitiske beslutninger de siste tiårene som har gått i tradisjonell kristen bioetikks disfavør. For det andre, og viktigst, at kristen bioetikk spesielt har mistet gjennomslag i offentlig debatt, og at det er særlig fem presumptivt rasjonelle grunner til dette. Argumentet for dette var en utlegning av grunnene til å avvise typiske kristne argumentasjonsformer, med eksempler på hvordan dette finner sted i aktuell offentlig debatt.

Som diskutert er trendene ikke enerådende, og de møter motstand også fra ikkekristne. Til de to påstandene vil jeg derfor avslutningsvis føye en tredje: at også ikkekristne bør vurdere de fem beskrevne trendene med et kritisk blikk. For hvis trendene $ø$ ker sin innflytelse, står argumentasjonsformer som også ikke-kristne tillegger stor verdi, i fare for å bli marginalisert i offentlig debatt. Norsk bioetisk debatt handler ofte om spørsmål om det gode liv og det gode samfunn. I et politisk liberalt paradigme trues slike agendaer med marginalisering - liberalismen vil akseptere at slike debatter har privat, men ikke politisk betydning. Liberalismen har blitt hevdet å ha en indre logikk som gjør at dens krav om økt likhet og frihet naturlig ekspanderer til stadig nye samfunnsområder (Kalb 2008).

Jeg har pekt på presumptivt rasjonelle grunner til at kristnes standpunkter og argumenter marginaliseres i det offentlige rom. Vi vet ikke om de ideologiske trendene vil fortsette å øke i betydning, eller avta og erstattes av andre. Men alle, både kristne og ikkekristne, bør spørre seg om de fem settene med grunner som jeg her har pekt på, virkelig er gode grunner i så måte - eller om de har uheldige trekk som bør problematiseres.

\section{Noter}

${ }^{1}$ Artikkelen bygger på en diskusjon i innledningskapitlet til min bok Menneskeverd i klinikk og politikk (Magelssen 2013: 12-17), der noen av momentene og eksemplene først ble nevnt.

${ }^{2}$ En av de fremste eksponentene for «public reason»-tenkningen er den liberale filosofen John Rawls se særlig Political Liberalism (1996) og «The Idea of Public Reason Revisited» (1997).

${ }^{3}$ Scientismen er den holdningen at kun naturvitenskapene prinsipielt kan gi opphav til kunnskap. 


\section{Referanser}

Academy of Royal Medical Colleges. (2011) Induced abortion and mental health. A systematic review of the mental health outcomes of induced abortion, including their prevalence and associated factors. London: Academy of Royal Medical Colleges.

Audi, R. (1993) The Place of Religious Argument in a Free and Democratic Society. San Diego Law Review, 30, s. 677-702.

Beckwith, F.J. (2001) Taking abortion seriously: A philosophical critique of the new anti-abortion rhetorical shift. Ethics \& Medicine, 17 (3), s. 155-166.

Beckwith, F.J. (2007) Defending Life. A Moral and Legal Case against Abortion Choice. Cambridge: Cambridge University Press.

Dadlez, E. \& Andrews, W.L. (2009) Post-Abortion Syndrome: Creating an Affliction. Bioethics, 24 (9), s. 445-452.

Eid-Hviding, T. (2012) Er datteren min en vare? Dagbladet, 6. desember.

Engelhardt, H.T. (1996) The Foundations of Bioethics (2. utg.). New York: Oxford University Press.

Engelhardt, H.T. (2000) The Foundations of Christian Bioethics. Salem, MA: M \& M Scrivener Press.

Erin, C.A. \& Harris, J. (2003) An ethical market in human organs. Journal of Medical Ethics, 29, s. $137-138$.

George, R.P. \& Tollefsen, C. (2008) Embryo: A defense of human life. New York: Doubleday Books.

Giubilini, A. \& Minerva, F. (2013) After-birth abortion: Why should the baby live? Journal of Medical Ethics, 39 (5), s. 261-263.

Gustavsen, Ø. \& Murtnes, S. (2012) Statstøttet brosjyre lærer ungdommer sadomasochisme. VG Nett, 27. juli 2012. Lastet ned fra http://www.vg.no/nyheter/innenriks/ artikkel.php?artid=10059434

Habermas, J. (2003) The Future of Human Nature. Cambridge: Polity Press.

Helsedirektoratet (2011) Evaluering av bioteknologiloven. Oslo: Helsedirektoratet.

Horn, M. (2010) Er aktiv dødshjelp etisk riktig? Verdidebatt.no, 4. oktober 2010. Lastet ned fra http://www.verdidebatt.no/debatt/cat12/subcat42/thread102086/

Kaczor, C. (2011) The Ethics of Abortion. Women's Rights, Human Life, and the Question of Justice. New York: Routledge.

Kalb, J. (2008) The Tyranny of Liberalism. Wilmington: ISI Books.

Kallestad, J. (2012) Kristent livssyn stuper på ny gallup. Vårt Land, 28. november 2012.

Koenig, H., King, D.E. \& Carson, V.B. (2012) Handbook of Religion and Health. New York: Oxford University Press.

Lee, E. (2003) Abortion, Motherhood, and Mental Health: Medicalizing Reproduction in the United States and Great Britian. New York: Aldine de Gruyter.

MacIntyre, A. (1990) Three Rival Versions of Moral Enquiry: Encyclopedia, Geneology, and Tradition. Notre Dame: University of Notre Dame Press.

Magelssen, M. (2010) «Skrevet i hjertet». Vårt indre moralske kompass. I Troverdig tro, red. M. Dahle Andersen, s. 201-211. Oslo: Luther forlag.

Magelssen, M. (2011) To teorier om fosterets moralske status. Norsk filosofisk tidsskrift, 46 (3), s. 199-211.

Magelssen, M. (2013) Menneskeverd i klinikk og politikk. Oslo: Lunde forlag.

Magelssen, M. \& Materstvedt, L.J. (2013) Å granske hjerter og nyrer: Ultralydens etikk. Nytt Norsk Tidsskrift, 30 (1), s. 28-40.

Marsden, G.E. (1997) The outrageous idea of Christian scholarship. Oxford: Oxford University Press.

Marthinsen, M. (2011) Ultralyd til besvær? VG, 16. februar 2011. 
Meilaender, G. (2005) Bioethics: A primer for Christians. Grand Rapids, MI: Wm. B. Eerdmans Publishing.

Melby, G. (2012) Retten til egne valg. Verdidebatt.no, 24. september 2012. Lastet ned fra http:// www.verdidebatt.no/debatt/cat12/subcat42/thread314476/

Mill, J.S. (1865) On Liberty. London: Longmans, Green, and Co.

Moen, O.M. (2012) Is prostitution harmful? Journal of Medical Ethics, nettpublisert 28. august 2012. Lastet ned fra http://jme.bmj.com/content/early/2012/08/27/medethics-2011100367.full.pdf

Murphy, M. (2008) The natural law tradition in ethics. I Stanford Encyclopedia of Philosophy, red. E.N. Zalta. Lastet ned fra: http://plato.stanford.edu/entries/natural-law-ethics/

O’Donovan, O. (1984) Begotten or made? Oxford: Oxford University Press.

Rawls, J. (1996) Political Liberalism. New York: Columbia University Press.

Rawls, J. (1997) The Idea of Public Reason Revisited. U. Chi. L. Rev., 64, s. 765-807.

Reardon, D. C. (2002) A defense of the neglected rhetorical strategy (NRS) Ethics \& Medicine, 18 (2), s. 23-32.

Sandel, M.J. (1998) Liberalism and the Limits of Justice. Cambridge: Cambridge University Press.

Skancke, T.W. (2007) Vi valgte bort et barn. Aftenposten, 24. februar 2007.

Sloan, R.P. (2006) Blind Faith. The Unholy Alliance of Religion and Medicine. New York: St. Martin's Griffin.

Solhjell, B.V. (2013) Slepp religionen inn. I Gud er tilbake!, red. S.K. Bjørndal, K.I. Tangen \& N. Strøm-Olsen, s. 34-47. Oslo: Frekk forlag.

Stiklestad, S.S. (2009) På sviktende kunnskapsgrunnlag? Assistert befruktning for lesbiske par. Etikk i praksis 3(2), s. 65-84.

Tooley, M. (1972) Abortion and infanticide. Philos Public Aff., 2 (1), s. 37-65.

Østnor, L. (2008) Stem cells, human embryos and ethics: Interdisciplinary perspectives. Dordecht: Springer. 